\title{
MICROWAVE DRYING OF CORN SEEDS: EFFECT OF TEMPERATURE ON DRYING TIME, ENERGY CONSUMPTION AND GERMINATION RATE
}

\author{
Á. H. Moreno ${ }^{1 *}$, R. Hernández-Maqueda ${ }^{2}$, I. Ballesteros², C. Torres-Miñoº \\ ${ }^{1}$ Facultad de Ciencias de la Ingeniería y Aplicadas. Universidad Técnica de Cotopaxi, Av. \\ Simón Rodríguez s/n. Barrio San Felipe, Latacunga, Ecuador \\ ${ }^{2}$ Facultad de Ciencias Agropecuarias y Recursos Naturales. Universidad Técnica de \\ Cotopaxi, Av. Simón Rodríguez s/n. Barrio San Felipe, Latacunga, Ecuador \\ angel.hernandez@utc.edu.ec \\ rafael.hernandez@utc.edu.ec \\ maria.ballesteros@utc.edu.ec \\ carlos.torres@utc.edu.ec
}

Keywords: microwave drying, corn seeds, drying time, energy consumption, germination rate

\begin{abstract}
In this work, the microwave drying of corn seeds at different temperatures has been studied. The main objective of this study is to evaluate the effect of the temperature on drying time, energy consumption and the germination rate of corn seeds after drying with microwave energy. The tests were performed in a domestic microwave oven at three drying temperatures $\left(35,55\right.$ and $\left.75^{\circ} \mathrm{C}\right)$. It was observed that an increase in the drying temperature causes a simultaneous decrease in drying time $(\sim 78 \%)$ and in the consumption of energy $(\sim 79 \%)$ required to dry the seeds. However, there is also an unacceptable decrease $(\sim 87 \%)$ in the germination rate of the seeds with the drying temperature. In order to increase the germination rates of corn seeds, after the drying process, it is necessary to employ drying temperatures between 35 and $50^{\circ} \mathrm{C}$.
\end{abstract}

\section{Introduction}

Corn or Maize (Zea mays L.), belongs to the grass family Poaceae (Gramineae), is the most extensively cultivated, produced and consumed cereal in the world [1]. Corn is considered as a staple food in many parts of the world and is also an important source of phytochemical compounds, such as carotenoids, phenolic compounds which could reduce the risk of several diseases such as atherosclerosis or cancer. Due to the presence of nutrients and phytochemicals it is considered as a healthy food [2]. Moreover, corn has a great economic importance worldwide not only as human food, but also as animal feed and as feedstock for a large quantity of industrial products and biofuels [1].

In Ecuador, the cultivation of corn crops has increased in the recent years. According to statistical information provided by the agricultural sector ESPAC 2018, Ecuador has increased its maize production levels considerably, even though, it is still deficient and needs to import large quantities of this cereal. In 2018, the area cultivated to dry hard corn nationwide was 383.399 hectares and this produced, approximately, 1.3 million tons of corn [3], a significant proportion of which was acquired by the national industry for the production of protein food. Moreover, based on reports of the Ecuadorian Central Bank [4], $55 \%$ of the credits granted to householders were destined to the production of several corn 
varieties, reflecting the importance of this crop in the country. For these reasons it is important to improve agricultural techniques in order to ensure an increase in the yield of corn crops.

Corn ears are usually harvested at a moisture content ranging from $22 \%$ to $40 \%$ (wb) in order to reduce the risk of frost, insect, disease damage and to maintain seed quality [5], [6], [7]. Corn harvested at these high moisture contents requires rapid drying for safe storage, to prevent respiration, germination, mold damage and insect infestation. Moreover, fungal spoilage and mycotoxin contamination are of major concern during corn storage [8]. To reduce or prevent the production of mycotoxins, drying is recommended immediately after harvesting [8]. It is very important to control the stage of drying and conservation of the seeds since poor management at this stage would result in substantial financial loss for the farmers.

The drying of corn, as other grains and seeds, can be performed naturally or artificially. Natural drying is the main method used by farmers in Cotopaxi as well as in other parts of Ecuador to dry the seeds, this consists in exposing them to the air, thereby taking advantage of solar energy. However, this method of drying has several disadvantages, such as we have pointed out in previous works [9], [10], [11], [12].

Several types of dryers have been developed for the drying of grains and cereals [13], [14], [15]. None of them, however, have proved suitable to satisfy all the needs and drying requirements of the different seeds. The grain drying system may be classified as Solar drying, Batch drying and Continuous-flow drying systems [14]. The dryers most commonly used to dry seeds are fixed bed dryers (batch) and sliding bed dryers, in their various configurations (concurrent, counter-current, and cross flows) [13], [14]. One of the first types of dryers used for drying corn seeds was the forced air dryer and many different innovative designs for forced-air corn drying have evolved in response to the needs of corn producers and processors [15]. However, this type of dryer has the disadvantage of requiring large amounts of thermal energy to vaporize the high moisture content of corn seeds. Therefore, the cost of producing this energy is the main disadvantage of this method.

In the drying process it is very important to control the temperature and humidity, since both factors are key for the growth viability of the seed. Most of authors consider that temperatures higher than $50^{\circ} \mathrm{C}$ are lethal for the viability of a seed, depending on the variety studied [6]. Moreover, the drying temperature has a significant effect on mechanical properties [16] and can cause mechanical damage to the seeds, in the form of stress cracking or kernel breakage [17]. Therefore, the control of temperature must be taken into account when designing an alternative drying method to sun drying. Microwave drying has great potential in this respect because this technique allows a good control of the process temperature, an increase in energy efficiency and a reduction of its carbon footprint [11], [18], [19].

Previous studies on the microwave drying of corn seeds have shown its effectiveness as a drying method [20], [21], although it should also be noted that the process parameters, in particular the temperature, play a very important role in determining the properties and quality of this grain [20]. Accordingly, the main objective of the present work is to evaluate the effect of the temperature on drying time, energy consumption and the germination rate of corn seeds after drying with microwave energy. 


\section{Materials and Methods}

\section{Materials}

The maize seeds used in this work were obtained by shelling $40 \mathrm{~kg}$ of ears that were purchased from farmers in Latacunga, Ecuador.

\section{Drying equipment and drying procedure}

The drying process of the corn seeds was carried out in a rotating turntable domestic multimode microwave oven (LACOR Model 69330) with a $900 \mathrm{~W}$ magnetron, using a frequency of $2.45 \mathrm{GHz}$ and a voltage of $220 \mathrm{~V}$. The microwave device is also equipped with a type $\mathrm{K}$ thermocouple connected to a PID controller Eurotherm $3216 \mathrm{~L}$ which controls the amount of power delivered and allows the temperature to be monitored and controlled.

In this oven, $100 \mathrm{~g}$ of corn seeds, with an initial humidity of between 16 and $20 \%(\mathrm{wb})$, was placed in a microwave plastic container (105 mm long, $105 \mathrm{~mm}$ wide and $45 \mathrm{~mm}$ high). The container, uncovered, was placed on the microwave oven dish (315 $\mathrm{mm}$ in diameter), and the thermocouple was immersed in the bed of seeds. The corn seeds were heated up to 3 drying temperatures $\left(35,55\right.$ and $\left.75{ }^{\circ} \mathrm{C}\right)$. All the experiments were carried out with the turntable in stationary mode to avoid fluctuations in the measurements of seed temperature. The seeds were weighed every 30 minutes, using a GASON balance (model Z1s, 300g x $0.01 \mathrm{~g}$ ), and the drying process was considered completed when a humidity of $12 \%$ was obtained. For each drying temperature studied, the experiments were carried out in duplicate.

\section{Energy consumption}

In each experiment, the electrical energy consumption was measured using a FLUKE 1735 energy analyzer. This analyzer allows the measurement of different electrical parameters, including current, voltage, power (active, reactive and apparent), frequency and energy consumption at specific time intervals. In this work the measurements of these parameters were recorded every 30 seconds.

\section{Germination tests}

The viability of the corn seeds dried in the microwave oven up to $12 \%$ humidity (wb), at the three temperatures under study, was evaluated by means of a Petri dish germination test. To perform this test, a sample of the dried seeds (20 seeds) was placed on a filter paper and a $20 \mathrm{~mL}$ volume of distillate water of was added to achieve sufficient humidity for them to sprout. The seeds were incubated at a temperature of $25^{\circ} \mathrm{C}$. For each temperature studied, a total of 5 replicates of the test were made. To evaluate the results of the germination test, the emergence of the radicle was taken into account and the time and percentage of germination of each of the 5 trials was determined. The average germination percentage for each drying temperature was then calculated. 


\section{Drying rate}

The drying rate (DR) of the seeds is the loss of mass (moisture) during the drying process per unit of time and per unit of dry mass $\left(\mathrm{g} \mathrm{H}_{2} \mathrm{O} /(\mathrm{g}\right.$ dry mass $\left.* \mathrm{~s})\right)$. The DR was determined according to the calculation procedure described in a previous work [12].

\section{Results and Discussion}

The results obtained from the drying of corn seeds in a multimode microwave oven at three different temperatures, as well as their effect on the drying time, energy consumption and viability of the seeds are as follows. The effect of the drying temperature on the three variables evaluated is shown in Fig. 1.

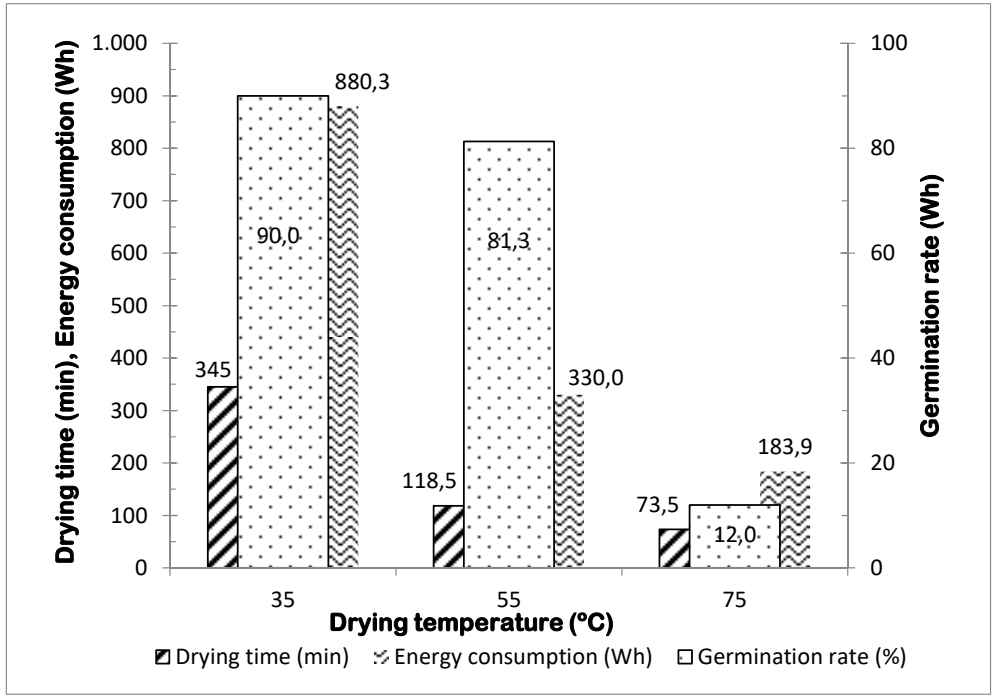

Fig. 1. Results of the microwave drying experiments of the corn seeds at different temperatures and their germination tests.

As can be seen in Fig1, as the drying temperature increases (from 35 to $75^{\circ} \mathrm{C}$ ) the drying times needed to reach a humidity of $12 \%$ decrease (from 345 to $74 \mathrm{~min}$ ), as a consequence of the increase in the drying rate of the seeds. This result agrees with the findings of other authors on microwave drying of corn seeds [20] and apples [22]. As the drying temperature increases, the maximum values of mass loss (maximum drying rate) increase, reaching magnitudes of $0.045,0.154$ and $0.565 \mathrm{~g}$ water/g dry mass $/ \mathrm{s} * 10^{-2}$ for drying temperatures of 35,55 and $75^{\circ} \mathrm{C}$, respectively. The high percentages of reduction of the drying time for the seeds with temperature, i.e. between 65 and $79 \%$ (See Table 1), are positive developments for reducing operating costs of the drying process.

Fig. 1 also illustrates the effect of the drying temperature on the energy consumption of microwave drying of corn seeds. It can be seen that as the drying temperature increases, the energy consumption required for the drying process of the seeds decreases significantly (between 62.5 and 79.1\%), especially in the case of the highest drying temperature (Table 1). This reduction in energy consumption with temperature is due to the much shorter drying times required to dry the seeds. The significant reduction of energy consumption in the 
drying process of the seeds is another very positive step towards the reduction of the operating costs of the drying process.

Table 1. Results of the microwave drying experiments of the corn seeds at different temperatures and their germination tests.

\begin{tabular}{cccc}
\hline $\begin{array}{c}\text { Drying temperature } \\
\left({ }^{\circ} \mathrm{C}\right)\end{array}$ & $\begin{array}{c}\text { Reduction in } \\
\text { drying time (\%) }\end{array}$ & $\begin{array}{c}\text { Reduction in energy } \\
\text { consumption (\%) }\end{array}$ & $\begin{array}{c}\text { Reduction in } \\
\text { germination rate (\%) }\end{array}$ \\
\hline 35 & - & - & - \\
55 & 65.7 & 62.5 & 9.7 \\
75 & 78.7 & 79.1 & 86.7 \\
\hline
\end{tabular}

Finally, it can be observed in Fig. 1 that at a drying temperature of $35^{\circ} \mathrm{C}$ the percentage of germination of the seed is good $(90 \%)$. However, when the drying temperatures increase, from 35 to $75^{\circ} \mathrm{C}$, there is significant reduction in the germination rate of the corn seeds (from $90 \%$ to $12 \%$ ). This behavior is due to the capacity of the seeds to germinate decreases because there is a reduction in the synthesis of proteins responsible for embryo respiration [23]. Moreover, at higher temperatures the seeds undergo mechanichal damage, such as internal tensions, cracks, breakages, and fractures [16], which also affects their ability to germinate. In fact, the reduction in germination rate $(86.7 \%)$ that occurs at $75^{\circ} \mathrm{C}$ is unacceptably high. In order to avoid affecting the germination capacity of the seeds and, consequently, obtain high germination rates in the microwave drying process of corn seeds, the drying temperatures must be maintained between 35 and $50^{\circ} \mathrm{C}$. This drying temperature interval has also been confirmed as optimal by other researchers [20].

\section{Conclusions}

From an analysis of the results obtained in this work the following conclusions can be drawn. The drying temperature has a significant effect on the microwave drying process and the germination rate of corn seeds. An increase in the drying temperature causes a simultaneous decrease in drying time $(\sim 78 \%)$ and in the consumption of energy $(\sim 79 \%)$ required to dry the seeds. This saving of time and energy makes the drying process of corn seeds much more competitive due to the decrease in operating costs. However, there is also an unacceptable decrease $(\sim 87 \%)$ in the germination rate of the corn seeds with the drying temperature. Therefore, for the implementation of microwave drying of corn seeds on a commercial scale the most suitable temperature to obtain high germination rates, is in the $35-50^{\circ} \mathrm{C}$ range. These seeds should not be dried at temperatures higher than $55^{\circ} \mathrm{C}$, due to the significant decrease in their germination rate.

\section{Acknowledgements}

The financial support received from Universidad Técnica de Cotopaxi (Ref. PI.EPSHMS.CIYA.2017) is greatly acknowledged. The authors also thank Cristian Hinojosa, Lili Tigasi and Daysi Pila for their contribution to the experimental work. 


\section{References}

[1] S. García-Lara and S. O. Serna-Saldivar, "Corn History and Culture", in Corn. Chemistry and Technology, 3rd ed., S. O. Serna-Saldivar, Ed. Oxford, UK: AACC International Press, 2019, ch. 1, pp. 1-18.

[2] T. R. Shah, K. Prasad, P. Kumar, "Maize - A potential source of human nutrition and health: A review", Cogent Food Agric., vol. 2, no. 2, pp. 1-9, 2016.

[3] INEC, "Encuesta de Superficie y Producción Agropecuaria Continua -ESPAC 2018", Instituto Nacional de Estadística y Censos (INEC), Quito, Ecuador, Abril, 2019.

[4] BCE, "Reporte de coyuntura del sector agropecuario". Publicaciones Técnicas Banco Central Ecuador (BCE), no. 90, III, pp. 1-38, Enero, 2018.

[5] J. S.Wall, C. James, and G. L. Donaldson, "Corn proteins: chemical and physical changes during drying of grain”, Cereal Chem., vol. 52, no. 6, pp. 779-790, 1975.

[6] R. J. Navratil, J. S. Burris, "The effect of drying temperature on corn seed quality", Can. J. Plant Sci., vol. 64, no. 3, pp. 487 - 496, July, 1984.

[7] U. Herter, J. S. Burris, "Preconditioning reduces the susceptibility to drying injury in corn seed", Can. J. Plant Sci., vol. 69, no, 3, pp. 775 - 789, July, 1989.

[8] S. N. Chulze, "Strategies to reduce mycotoxin levels in maize during storage: a review Part A Chemistry, analysis, control, exposure \& risk assessment”, Food Addit. Contam., vol. 27, no. 5, pp. 651-657, 2010.

[9] Á. H. Moreno, R. Hernández Maqueda, I. Ballesteros, "Microwave drying of seeds and vegetable products: a viable option for Ecuador", in Proc. of the 3rd Global Congress on Microwave Energy Applications (3GCMEA), J. Fayos-Fernández and J. MonzóCabrera, Eds., Cartagena, Spain, 2016, pp. 103-108.

[10] Á. H. Moreno, R. Hernández Maqueda, I. Ballesteros, "Microwave Drying of Seeds of Agricultural Interest for Ecuador", AMPERE Newsl., no. 92, pp. 28-32, April, 2017.

[11] Á. H. Moreno, R. Hernández Maqueda, I. Ballesteros, "Secado industrial con energía microondas", in Aplicaciones industriales del calentamiento con energía microondas, J. A. Menéndez, Á. H. Moreno, Eds., Latacunga, Ecuador: Univ. Téc. de Cotopaxi, 2017, Ch. 5, pp. 85-118.

[12] R. Hernández Maqueda, I. Ballesteros, S. Jiménez Jácome, Á. H Moreno, “Microwave drying of amaranth and quinoa seeds: effects of the power density on the drying time, germination rate and seedling vigour", J. Microw. Power Electromagn. Energy, vol. 52, no. 4, pp. 299-311, 2018.

[13] M. A. S. Barrozo, A. Mujumdar, J. T. Freire, “Air-Drying of Seeds: A Review”, Drying Technol., vol. 32, no. 10, pp. 1127-1141, 2014.

[14] B. K Bala, Drying and Storage of Cereal Grains. Second Edition. Wiley-Blackwell, 2016.

[15] C. J. Bern, G. Quick, F. L. Herum, "Harvesting and Postharvest Management", in Corn. Chemistry and Technology, 3rd ed., S. O. Serna-Saldivar, Ed. Oxford, UK: AACC International Press, 2019, ch. 5, pp. 109-145.

[16] S. Abasi, S. Minaei, "Effect of Drying Temperature on Mechanical Properties of Dried Corn", Drying Technol., vol. 32, no. 7, pp. 774-780, 2014.

[17] S. Mason, N. D'croz-Mason, “Agronomic Practices Influence Maize Grain Quality”, $J$. Crop Prod., vol. 5, no. 1-2, pp. 75-91, 2002.

[18] R. F. Schiffmann, "Microwave and Dielectric Drying", in Handbook of the Industrial Drying $4^{\text {th }}$ Ed., A. S. Mujumdar, Ed., Boca Raton, FL., US, 2015, Ch. 13, pp. 283-302.

[19] P. Rattanadecho, N. Makul, "Microwave-Assisted Drying: A Review of the State ofthe-Art”, Drying Technol., vol. 34, no. 1, pp. 1-38, 2016. 
[20] G. R. Nair, Z. Li, Y. Gariepy, V. Raghavan, "Microwave Drying of Corn (Zea mays L. ssp.) for the Seed Industry", Drying Technol., vol. 29, no. 11, pp. 1291-1296, 2011.

[21] S. Gürsoy, R. Choudhary, D. G Watson, "Microwave drying kinetics and quality characteristics of corn”, Int. J Agric. \& Biol. Eng., vol. 6, no. 1, pp. 90-99, March, 2013.

[22] Z. Li, G. S. V. Raghavan, V. Orsat, "Temperature and power control in microwave drying", J. Food Eng., vol. 97, no. 4, pp. $478-483,2010$.

[23] G. Riley, "Effects of high temperature on the germination of maize (Zea mays L.)", Planta, vol. 151, no. 1, pp. 68-74, 1981. 